\title{
Risk Factors on Healthcare-Associated Infections Among Hospitalized Tuberculosis Patients in China From 2001-2020: A Systematic Review and Meta- Analysis
}

\section{Xinliang Liu}

Wuhan University

Nili Ren

Wuhan Pulmonary Hospital, Wuhan Institute for Tuberculosis Control

Zheng Feei Ma

Xi'an Jiaotong-Liverpool University

Meiling Zhong

Wuhan University

Hao Li ( $\sim$ h.li@whu.edu.cn )

Wuhan University

\section{Research Article}

Keywords: Tuberculosis, Healthcare-associated infections, Risk factors, China

Posted Date: December 14th, 2021

DOI: https://doi.org/10.21203/rs.3.rs-1085813/v1

License: (c) (i) This work is licensed under a Creative Commons Attribution 4.0 International License. Read Full License

Version of Record: A version of this preprint was published at BMC Infectious Diseases on April 20th, 2022. See the published version at https://doi.org/10.1186/s12879-022-07364-9. 


\section{Abstract}

\section{Background}

As a chronic communicable disease, tuberculosis (TB) is acknowledged as a global public health issue. A comprehensive analysis of risk factors on HAls among TB hospitalized patients in Chinese hospitals is vacant. The aim of this systematic review and meta-analysis is to investigate the risk factors associated with healthcare-associated TB in Chinese hospitals.

\section{Methods}

Medline, EMBASE and Chinese Journals Online databases were searched. The search was limited to studies published from January 1st 2001 and December 31st 2020. Meta-analyses of ORs in the prevalence were estimated. Heterogeneity between studies was assessed based on the $\boldsymbol{\tau}^{2}$ and $R$ statistics to select the meta-analysis model. Review Manager 5.3 was employed and $P<0.05$ was considered as the statistical significance.

\section{Results}

The databases searched 418 records, of which 11 published articles were included in the quantitative meta-analysis. A total of 11,922 TB hospitalized patients were included in the systematic review and meta-analysis, of which 1,133 were diagnosed as having HAls. Older than 65 years (OR: 2.89[2.01-4.15]), presence of complication (OR: 3.28[2.10-5.13]), presence of diabetes mellitus (OR: 1.63[1.22-2.19]), invasive procedure (OR: 3.80[2.25-6.42]), longer than 15 days of hospitalization stay (OR: 2.09[1.64-2.64]), secondary tuberculosis (OR: 2.25[1.48-3.42]), smoking (OR: 1.40[1.02-1.93]), presence of underlying disease (OR: 2.66[1.53-4.62]), and use of antibiotics (OR: 2.77[2.35-3.27]) were the main risk factors associated with higher HAls prevalence among TB hospitalized patients with a statistical significance $(P<0.05)$.

\section{Conclusions}

older than 65 years, presence of complication, presence of diabetes mellitus, invasive procedure, longer than 15 days of hospitalization stay, secondary tuberculosis, smoking, presence of underlying disease, and use of antibiotics were the main risk factors which had a negative impact on HAls among TB hospitalized patients in Chinese hospitals. These findings provided evidence for the policy makers and hospital managers to make effective infection prevention and control measures to constrain the rising of HAls. It is also required that more cost-effective infection prevention and control measures should be widely applied in routinely medical treatment and clinical management to healthcare-associated TB.

\section{Introduction}

As a chronic communicable disease, tuberculosis (TB) is acknowledged as a global public health issue, because it is one of the 10 top causes of disability and a leading cause of death globally (1). In 2019 , the 
World Health Organization (WHO) reported that around 10.0 million people were infected with TB and 1.4 million died in 198 countries and territories (2). Particularly, China had the third highest burden of TB in the world and $8.4 \%$ of all global cases were detected in China (2). Since the pandemic of COVID-19 is threatening the globe, it reverses the deduction on TB incidence by having a negative impact on the Gross Domestic Product (GDP) per capita and undernutrition, which are two key determinants of TB incidence. The WHO estimated that TB cases could increase by more than 1 million per year in the period 2020-2025 because of the COVID-19 pandemic (2). This exacerbates the situation of diminishing TB.

Hospitals, as the main body to provide health care to treat TB, are also the main repository of healthcareassociated infections (HAls). HAls are an adverse outcome during providing health care to patients in hospitals. It affects patients' safety and extends the hospitalization, thereby patients suffering from the increasing morbidity and mortality $(3,4)$. HAls are also a global public health problem. In 2011 , the WHO conducted a literature review and indicated that 7 and 10 out of every 100 hospitalized patients had a HAI in high-income countries and middle-income countries respectively $(5,6)$. The HAls prevalence in China was estimated around 3 out of every 100 hospitalized patients in 2018 (7). Although it was lower than that reported by the WHO, China has the largest population in the world. This still indicates China has a high burden attributable to HAls.

Usually, a TB patient needs to be treated with multiple antibiotics for 6 to 12 months (3). This results in a long time exposure to antibiotics for patients. Antibiotics use in many studies has been recognised as one of the risk factors to increase HAls incidence $(8,9)$. As for TB patients themselves, especially the elderly, they have a low immunity to fight against the infection (10). As a consequence, TB patients are at high risk to get HAls. Therefore, it is essential for health professionals and managers to understand what kind of risk factors have an impact on healthcare-associated TB. Thus, it can contribute to guideline and regulation about constraining healthcare-associated TB in hospitals.

Several studies investigating the potential risk factors on healthcare-associated TB have been conducted in China However, all of them were based on a single hospital, which is sporadic. There is still scare evidence-based guideline or regulation to help health professionals and hospital managers to increase the awareness of the hazards of healthcare-associated TB and take effective infection control measures to constrain the occurrence of healthcare-associated TB. The aim of this systematic review and metaanalysis is to investigate the risk factors associated with healthcare-associated TB between patients with HAls and those without HAls in Chinese hospitals.

\section{Methodology}

\section{Systematic search strategy}

The PICO/S (Population, Intervention, Comparison, Outcome, and Study type) tool was applied to define the scope of the literature.

Population: hospitalized TB patients admitted to the hospitals more than $48 \mathrm{hrs}$ 
Intervention: healthcare-associated infections (diagnosed by the definition proposed by the Ministry of Health, People's Republic of China (11))

Comparison: hospitalized TB patients without HAls

Outcome: HAls prevalence

Study type: cross-sectional study, case-control study or cohort study

This systematic review was conducted corresponding to the Preferred Reporting Items for Systematic Reviews and Meta-analysis (PRISMA) guidelines. Medline, EMBASE and Chinese Journals Online databases (China National Knowledge Infrastructure [CNKI], Chinese Wan Fang digital database and Chinese Science and Technique Journals Database [VIP]) were searched. The studies published were limited from 1st January 2001 to31st December 2020, since the version of diagnosis of HAls was published in 2001 in China.

Search Chinese corresponding terms in the title, abstract and keywords included healthcare-associated infections/cross infections/hospital acquired infections/nosocomial infections, tuberculosis, risk factors/influencing factors/ and China for the Chinese databases. The logical word is "AND". As to Medline and EMBASE, medical subject heading (MeSH) terms in key words were adopted. The MeSH terms were ("cross infection" AND "tuberculosis" AND "risk factors" AND "China").

\section{Inclusion and exclusion criteria}

The inclusion criteria were as follows: 1) risk factors analysis by using a case-control or cohort study; 2) a multi-centre study or a single-centre study; 3 ) study language being either English or Chinese.

The exclusion criteria were as follows: 1) conference papers or editorials/letters; 2) duplicate studies and repeated data published in different journals concurrently; 3 ) any study outside China; 4) only description on the prevalence or landscape of HAls; 5) risk factors concluded without any statistical inference (e.g. according to the clinical experience).

\section{Data abstraction}

Two independent reviewers (X.L. and N.R.) screened the obtained literature by title and abstract to determine the eligibility of studies. Potential disagreement was resolved by discussion. Identified studies were retrieved in full text and were checked again for eligibility. In case of exclusion of the study the reason was documented. Moreover, cross-references were also considered by screening the bibliography of eligible studies as well as bibliography of cross-references.

\section{Quality assessment of the included studies on risk factors for HAls among TB hospitalized patients}

X.L. and N.R. jointly assessed the quality of the included studies for risk factors analysis associated with HAls among TB hospitalized patients according to the criteria of JBI' (Joanna Briggs Institute) critical 
appraisal tools (12). This tool includes 8 questions to identify the quality of a cross-sectional study. For each question, there are 4 options to choose (Yes, Unclear, No and Not applicable). The less the number of a positive option (Yes) is, the more the uncertainty of a study is. Otherwise, the quality of a study is better. Moreover, a value was assigned to each answer in order to calculate the scores for each study, that is, 2 points for 'Yes', 1 point for 'Unclear or Not applicable', and 0 point for 'No'.

\section{Statistical analysis}

Review Manager 5.3 software was deployed to assess the risk factor odds ratio (OR) among TB hospitalized patients. Meta-analyses of OR in HAl prevalence were performed. Heterogeneity between studies was assessed based on the $\hat{\tau}^{2}$ and $R$ statistics to select the meta-analysis model. When results had a $\hat{\tau}^{2}(P<0.05)$ and/or $R>50 \%$, data were considered heterogeneous and the random-effects model was used; otherwise, the fixed-effects model was used. $P<0.05$ was considered as a statistical significance.

\section{Results}

\section{Characteristics of eligible studies}

Figure 1 shows that totally, 851 records were searched from the included databases. Eventually, 11 published articles were incorporated in the quantitative meta-analysis after reading the eligible full texts with the inclusion and exclusion criteria.

\section{Integration of the included studies on risk factors between patients with HAls and patients without HAls among TB hospitalized patients}

Table 1 presents that in total, 11,922 TB hospitalized patients were included in the systematic review and meta-analysis. Of them, 1,133 were diagnosed as having HAls, while the rest $(110,789)$ were not with HAls. All of the included studies were undertaken in tertiary general hospitals, which covered 10 regions in 9 provinces in China. Table 2 shows that the most frequent risk factors reported from the included studies were age (11/11), use of antibiotics (11/11), invasive procedure (9/11), and length of hospitalization $(9 / 11)$. 
Table 1

Characteristics of the studies included in the systematic and meta-analysis on risk factors for healthcareassociated infections among TB hospitalized patients in Chinese general hospitals from 2001 to 2020

\begin{tabular}{|c|c|c|c|c|c|c|c|}
\hline \multirow[t]{2}{*}{$\begin{array}{l}\text { Study } \\
\text { ID }\end{array}$} & \multirow[t]{2}{*}{ Author (Year) } & \multirow[t]{2}{*}{ Study design } & \multirow[t]{2}{*}{$\begin{array}{l}\text { Study } \\
\text { setting }\end{array}$} & \multirow[t]{2}{*}{$\begin{array}{l}\text { Region } \\
\text { (Province) }\end{array}$} & \multirow{2}{*}{$\begin{array}{l}\text { Year } \\
\text { begun } \\
\text { and } \\
\text { duration } \\
\text { (years) }\end{array}$} & \multicolumn{2}{|c|}{$\begin{array}{l}\text { Number of } \\
\text { participants }\end{array}$} \\
\hline & & & & & & HAls & $\begin{array}{l}\text { Non- } \\
\text { HAls }\end{array}$ \\
\hline $\begin{array}{l}\text { Xiang } \\
\text { et al. } \\
(2019) \\
(22)\end{array}$ & $\begin{array}{l}\text { Retrospective } \\
\text { cross- } \\
\text { sectional }\end{array}$ & $\begin{array}{l}\text { One tertiary } \\
\text { hospital }\end{array}$ & Qiongqing & 2015,2 & 400 & 1,901 & \\
\hline $\begin{array}{l}\text { Jiang } \\
\text { et al. } \\
(2019) \\
(21)\end{array}$ & $\begin{array}{l}\text { Retrospective } \\
\text { cross- } \\
\text { sectional }\end{array}$ & $\begin{array}{l}\text { One tertiary } \\
\text { hospital }\end{array}$ & $\begin{array}{l}\text { Xining } \\
\text { (Qinghai) }\end{array}$ & $2016,1.5$ & 32 & 269 & \\
\hline 3 & $\begin{array}{l}\text { Zhou et al. } \\
\text { (2018) (19) }\end{array}$ & $\begin{array}{l}\text { Retrospective } \\
\text { cross- } \\
\text { sectional }\end{array}$ & $\begin{array}{l}\text { One } \\
\text { tertiary } \\
\text { hospital }\end{array}$ & $\begin{array}{l}\text { Baoding } \\
\text { (Hebei) }\end{array}$ & $\begin{array}{l}2015 \\
2.5\end{array}$ & 152 & 2,234 \\
\hline 4 & $\begin{array}{l}\text { Huang et al. } \\
(2019)(20)\end{array}$ & $\begin{array}{l}\text { Retrospective } \\
\text { cross- }^{-} \\
\text {sectional }\end{array}$ & $\begin{array}{l}\text { One } \\
\text { tertiary } \\
\text { hospital }\end{array}$ & $\begin{array}{l}\text { Danzhou } \\
\text { (Hainan) }\end{array}$ & 2015,1 & 78 & 78 \\
\hline 5 & $\begin{array}{l}\text { Chen et al. } \\
(2018)(13)\end{array}$ & $\begin{array}{l}\text { Retrospective } \\
\text { cross- } \\
\text { sectional }\end{array}$ & $\begin{array}{l}\text { One } \\
\text { tertiary } \\
\text { hospital }\end{array}$ & $\begin{array}{l}\text { Wenling } \\
\text { (Zhejiang) }\end{array}$ & 2014,3 & 28 & 653 \\
\hline 6 & $\begin{array}{l}\text { Liu et al. } \\
\text { (2015) (15) }\end{array}$ & $\begin{array}{l}\text { Retrospective } \\
\text { cross- } \\
\text { sectional }\end{array}$ & $\begin{array}{l}\text { One } \\
\text { tertiary } \\
\text { hospital }\end{array}$ & $\begin{array}{l}\text { Zhuhai } \\
\text { (Guangdong) }\end{array}$ & 2005,9 & 79 & 1,225 \\
\hline 7 & $\begin{array}{l}\text { Dai et al. } \\
\text { (2014) (14) }\end{array}$ & $\begin{array}{l}\text { Retrospective } \\
\text { cross- } \\
\text { sectional }\end{array}$ & $\begin{array}{l}\text { One } \\
\text { tertiary } \\
\text { hospital }\end{array}$ & $\begin{array}{l}\text { Wenzhou } \\
\text { (Zhejiang) }\end{array}$ & 2012,1 & 30 & 286 \\
\hline 8 & $\begin{array}{l}\text { Gong \& } \\
\text { Wang (2013) } \\
\text { (39) }\end{array}$ & $\begin{array}{l}\text { Retrospective } \\
\text { cross- } \\
\text { sectional }\end{array}$ & $\begin{array}{l}\text { One } \\
\text { tertiary } \\
\text { hospital }\end{array}$ & $\begin{array}{l}\text { Binzhou } \\
\text { (Shandong) }\end{array}$ & 2006,7 & 142 & 1,858 \\
\hline 9 & $\begin{array}{l}\text { Zhang et al. } \\
\text { (2012) (17) }\end{array}$ & $\begin{array}{l}\text { Retrospective } \\
\text { cross- }^{-} \\
\text {sectional }\end{array}$ & $\begin{array}{l}\text { One } \\
\text { tertiary } \\
\text { hospital }\end{array}$ & $\begin{array}{l}\text { Weihui } \\
\text { (Henan) }\end{array}$ & $\begin{array}{l}2008 \\
3.5\end{array}$ & 117 & 756 \\
\hline 10 & $\begin{array}{l}\text { Zhong et al. } \\
\text { (2010) (18) }\end{array}$ & $\begin{array}{l}\text { Retrospective } \\
\text { cross- } \\
\text { sectional }\end{array}$ & $\begin{array}{l}\text { One } \\
\text { tertiary } \\
\text { hospital }\end{array}$ & $\begin{array}{l}\text { Foshan } \\
\text { (Guangdong) }\end{array}$ & 2007,1 & 56 & 1,306 \\
\hline 11 & $\begin{array}{l}\text { Zeng (2015) } \\
\text { (16) }\end{array}$ & $\begin{array}{l}\text { Retrospective } \\
\text { cross- }^{-} \\
\text {sectional }\end{array}$ & $\begin{array}{l}\text { One } \\
\text { tertiary } \\
\text { hospital }\end{array}$ & $\begin{array}{l}\text { Foshan } \\
\text { (Guangdong) }\end{array}$ & 2010,4 & 19 & 223 \\
\hline
\end{tabular}


Table 2

Frequency of the identified risk factors in the included studies on risk factors for healthcare-associated infections among TB hospitalized patients in Chinese general hospitals from 2001 to 2020

\begin{tabular}{|c|c|c|c|c|c|c|c|c|c|c|c|c|}
\hline Study ID/Risk factors & 1 & 2 & 3 & 4 & 5 & 6 & 7 & 8 & 9 & 10 & 11 & Total \\
\hline Age & $\sqrt{ }$ & $\sqrt{ }$ & $\sqrt{ }$ & $\sqrt{ }$ & $\sqrt{ }$ & $\sqrt{ }$ & $\sqrt{ }$ & $\sqrt{ }$ & $\sqrt{ }$ & $\sqrt{ }$ & $\sqrt{ }$ & 11 \\
\hline AIDS & & & & & & $\sqrt{ }$ & & & & & & 1 \\
\hline Albumin ( $>40 \mathrm{~g} / \mathrm{L}$ vs. $\leq 40 \mathrm{~g} / \mathrm{L})$ & & $\sqrt{ }$ & & & & & & & & & & 1 \\
\hline Complications & & & & & $\sqrt{ }$ & & & & & $\sqrt{ }$ & $\sqrt{ }$ & 3 \\
\hline $\begin{array}{l}\text { Course of disease (> } 5 \text { years vs. } \leq 5 \\
\text { years) }\end{array}$ & & $\sqrt{ }$ & & & & & & & & & & 1 \\
\hline Diabetes mellitus & & & $\sqrt{ }$ & & & $\sqrt{ }$ & & & & & & 2 \\
\hline Gender & $\sqrt{ }$ & $\sqrt{ }$ & $\sqrt{ }$ & $\sqrt{ }$ & $\sqrt{ }$ & $\sqrt{ }$ & $\sqrt{ }$ & & $\sqrt{ }$ & & & 8 \\
\hline Invasive procedure & & $\sqrt{ }$ & $\sqrt{ }$ & $\sqrt{ }$ & $\sqrt{ }$ & & $\sqrt{ }$ & $\sqrt{ }$ & $\sqrt{ }$ & $\sqrt{ }$ & $\sqrt{ }$ & 9 \\
\hline Length of hospitalization & & $\sqrt{ }$ & $\sqrt{ }$ & $\sqrt{ }$ & $\sqrt{ }$ & & $\sqrt{ }$ & $\sqrt{ }$ & $\sqrt{ }$ & $\sqrt{ }$ & $\sqrt{ }$ & 9 \\
\hline $\begin{array}{l}\text { Negativity of the sputum smear for } \\
\text { acid fact staining }\end{array}$ & $\sqrt{ }$ & $\sqrt{ }$ & & & & & & & & & & 2 \\
\hline Secondary tuberculosis & $\sqrt{ }$ & $\sqrt{ }$ & & & & $\sqrt{ }$ & & & & & & 3 \\
\hline Smoking & & & $\sqrt{ }$ & & $\sqrt{ }$ & & & & & & & 2 \\
\hline Tuberculosis retreatment & $\sqrt{ }$ & & & & & & & & & & & 1 \\
\hline Underlying diseases & $\sqrt{ }$ & $\sqrt{ }$ & $\sqrt{ }$ & $\sqrt{ }$ & & & & $\sqrt{ }$ & $\sqrt{ }$ & & & 6 \\
\hline Use of antibiotics & $\sqrt{ }$ & $\sqrt{ }$ & $\sqrt{ }$ & $\sqrt{ }$ & $\sqrt{ }$ & $\sqrt{ }$ & $\sqrt{ }$ & $\sqrt{ }$ & $\sqrt{ }$ & $\sqrt{ }$ & $\sqrt{ }$ & 11 \\
\hline Use of anti-tuberculous drug & & & & $\sqrt{ }$ & & & & $\sqrt{ }$ & & & & 2 \\
\hline Use of glucocorticoid & $\sqrt{ }$ & & & & & & & & & & & 1 \\
\hline
\end{tabular}

\section{Quality assessment of the included studies}

All of the 11 included studies were cross-sectional with a median score (10 points). All of the studies clearly defined the inclusion for the hospitalized patients, identified the confounding factors which had an impact on the occurrence of HAls among TB hospitalized patients, and measured the outcomes in a valid and reliable way. However, none of the studies described the study setting with more details and only mentioned the hospital without any details. Also, variation of the HAls prevalence existed among the included studies. It mainly showed that some studies did not describe how the HAls prevalence among the TB hospitalized patients was calculated. The same situation was also applied to the standard criteria for the TB patients with HAls and the strategy to deal with the confounding factors. (See Appendix 1) 


\section{Meta-analyses of all the potential risk factors}

Table 3shows that a total of 11 risk factors were included in the meta-analyses. The forest plot of each risk factor was presented in Supplementary Material: Appendix 2. Specific results were shown as follows. 
Table 3

The pooled ORs of the risk factors estimated in the meta-analyses between the patients with HAls and the patients without HAls among TB hospitalized patients

\begin{tabular}{|c|c|c|c|c|c|c|c|}
\hline \multirow[t]{2}{*}{ Risk factors } & \multicolumn{2}{|c|}{$\begin{array}{l}\text { Number of } \\
\text { patients }\end{array}$} & \multirow{2}{*}{$\begin{array}{l}\text { Meta- } \\
\text { analysis } \\
\text { model }\end{array}$} & \multirow{2}{*}{$\begin{array}{l}\text { OR } \\
{[95 \%} \\
\text { Cl] }\end{array}$} & \multirow[t]{2}{*}{$\hat{\tau}^{2}(P)$} & \multirow[t]{2}{*}{$\begin{array}{l}R \\
(\%)\end{array}$} & \multirow[t]{2}{*}{$P$-value } \\
\hline & HAls & $\begin{array}{l}\text { Non- } \\
\text { HAls }\end{array}$ & & & & & \\
\hline Age ( $\geq 65$ years vs. $<65$ years) & 481 & 6,686 & $\begin{array}{l}\text { Random- } \\
\text { effects }\end{array}$ & $\begin{array}{l}2.89 \\
{[2.01-} \\
4.15]\end{array}$ & $\begin{array}{l}0.14 \\
(0.006)\end{array}$ & 67 & $<0.01^{*}$ \\
\hline Complications & 103 & 2,182 & $\begin{array}{l}\text { Fixed- } \\
\text { effects }\end{array}$ & $\begin{array}{l}3.28 \\
{[2.10-} \\
5.13]\end{array}$ & - & 0 & $<0.01^{\star}$ \\
\hline Diabetes mellitus & 231 & 3,459 & $\begin{array}{l}\text { Fixed- } \\
\text { effects }\end{array}$ & $\begin{array}{l}1.63 \\
{[1.22-} \\
2.19]\end{array}$ & - & 0 & $0.0009 *$ \\
\hline Gender & 916 & 7,402 & $\begin{array}{l}\text { Fixed- } \\
\text { effects }\end{array}$ & $\begin{array}{l}1.04 \\
{[0.90-} \\
1.21]\end{array}$ & - & 0 & 0.55 \\
\hline Invasive procedure & 512 & 5,805 & $\begin{array}{l}\text { Random- } \\
\text { effects }\end{array}$ & $\begin{array}{l}3.80 \\
{[2.25-} \\
6.42]\end{array}$ & $\begin{array}{l}0.39 \\
(<0.01)\end{array}$ & 78 & $<0.01 *$ \\
\hline $\begin{array}{l}\text { Length of hospitalization (> } \\
15 \text { days vs. } \leq 15 \text { days) }\end{array}$ & 317 & 4,971 & $\begin{array}{l}\text { Fixed- } \\
\text { effects }\end{array}$ & $\begin{array}{l}2.09 \\
{[1.64-} \\
2.64]\end{array}$ & - & 44 & $<0.01^{\star}$ \\
\hline $\begin{array}{l}\text { Negativity of the acid-fast } \\
\text { bacilli (AFB) smear and } \\
\text { culture }\end{array}$ & 432 & 2,170 & $\begin{array}{l}\text { Random- } \\
\text { effects }\end{array}$ & $\begin{array}{l}1.23 \\
{[0.41-} \\
3.65]\end{array}$ & $\begin{array}{l}0.54 \\
(0.006)\end{array}$ & 87 & 0.71 \\
\hline Secondary tuberculosis & 511 & 3,395 & $\begin{array}{l}\text { Random- } \\
\text { effects }\end{array}$ & $\begin{array}{l}2.25 \\
{[1.48-} \\
3.42]\end{array}$ & $\begin{array}{l}0.08 \\
(0.10)\end{array}$ & 56 & $0.0001 *$ \\
\hline Smoking & 180 & 2,887 & $\begin{array}{l}\text { Fixed- } \\
\text { effects }\end{array}$ & $\begin{array}{l}1.40 \\
{[1.02-} \\
1.93]\end{array}$ & - & 0 & $0.04 *$ \\
\hline Underlying disease & 779 & 5,238 & $\begin{array}{l}\text { Random- } \\
\text { effects }\end{array}$ & $\begin{array}{l}2.66 \\
{[1.53-} \\
4.62]\end{array}$ & $\begin{array}{l}0.33 \\
(<0.01)\end{array}$ & 87 & $0.0005^{*}$ \\
\hline Use of antibiotics & 991 & 8,931 & $\begin{array}{l}\text { Fixed- } \\
\text { effects }\end{array}$ & $\begin{array}{l}2.77 \\
{[2.35-} \\
3.27]\end{array}$ & - & 45 & $<0.01^{\star}$ \\
\hline
\end{tabular}

Note: * means the statistical significance at $P<0.05$. 
Age ( $>60$ years vs. $\leq 60$ years): 7 studies (13-19) reported the age ( $>60$ years) of 279 with and 2,327 TB patients without HAls. Random-effects model showed that the prevalence of HAls was significantly higher $(P<0.01)$ in patients who were over 60 years old than those who were younger than 60 years old (OR: $2.89,95 \% \mathrm{Cl}: 2.01-4.15)$. There was a middle level of heterogeneity among the studies $\hat{\tau}^{2}=0.14$ $\left.(P=0.006), I^{2}=67 \%\right)$.

Complications: 3 studies $(13,16,18)$ reported the complications of 74 with and 943 patients without HAls. Fixed-effects model showed that the prevalence of HAls was significantly higher $(P<0.01)$ in patients with complications than those without complications (OR: 3.28, 95\% Cl: 2.10-5.13). The heterogeneity did not exist among the studies $\left(P=0.74, \mathrm{I}^{2}=0 \%\right)$.

Diabetes mellitus: 2 studies $(15,19)$ reported the diabetes mellitus of 103 with and 1,177 patients without HAls. Fixed-effects model showed that the prevalence of HAls was significantly higher $(P=0.0009)$ in patients with diabetes mellitus than those without diabetes mellitus (OR: 1.63, 95\% Cl: 1.22-2.19). The heterogeneity did not exist among the studies $\left(P=0.75, I^{2}=0 \%\right)$.

Gender: 8 studies $(13-15,17,19-22)$ reported the gender (Male) of 539 with and 4,331 patients without HAls. Fixed-effects model showed that the prevalence of HAls was almost equal $(P=0.55)$ between male patients and female patients (OR: $1.04,95 \% \mathrm{Cl}: 0.90-1.21)$. The heterogeneity did not exist among the studies $\left(P=0.83, I^{2}=0 \%\right)$.

Invasive procedure: 8 studies $(13,14,16-21)$ reported the invasive procedure of 225 with and 1,830 patients without HAls. Random-effects model showed that the prevalence of HAls was significantly higher $(P<0.01)$ in patients who experienced invasive procedure than those who did not experience invasive procedure (OR: $3.80,95 \% \mathrm{Cl}: 2.25-6.42)$. There was a high heterogeneity among the studies $\hat{\tau}^{2}$ $\left.=0.39(P<0.01), I^{2}=78 \%\right)$.

Length of hospitalization ( $>15$ days vs. $\leq 15$ days): 6 studies $(13,14,16,18,19,21)$ reported the length of hospitalization (>15 days) of 200 with and 2,318 patients without HAls. Fixed-effects model showed that the prevalence of HAls was significantly higher $(P<0.01)$ in patients who had length of hospitalization over 15 days than those who had length of hospitalization less than 15 days (OR: 2.09, 95\% Cl: 1.642.64). The heterogeneity did not exist among the studies $\left(P=0.11, I^{2}=44 \%\right)$.

Negativity of the acid-fast bacilli (AFB) smear and culture: 2 studies $(21,22)$ reported the negativity of the acid-fast bacilli (AFB) smear and culture of 77 with and 310 patients without HAls. Random-effects model showed that the prevalence of HAls was higher $(P=0.71)$ in patients who had negativity of the acidfast bacilli (AFB) smear and culture than those who had positivity of the acid-fast bacilli (AFB) smear and culture (OR: $1.23,95 \% \mathrm{Cl}: 0.41-3.65)$. There was a high heterogeneity among the studies $\hat{\tau}^{2}=0.54$ $\left.(P=0.006), I^{2}=87 \%\right)$. 
Secondary tuberculosis: 3 studies $(15,21,22)$ reported the secondary tuberculosis of 145 with and 611 patients without HAls. Random-effects model showed that the prevalence of HAls was significantly higher $(P=0.0001)$ in patients who had secondary tuberculosis than those who did not have secondary tuberculosis (OR: $2.25,95 \% \mathrm{Cl}: 1.48-3.42)$. There was a middle level of heterogeneity among the studies $\left.\hat{\tau}^{2}=0.08(P=0.10), I^{2}=56 \%\right)$.

Smoking: 2 studies $(13,19)$ reported the smoking of 111 with and 1,500 patients without HAls. The fixedeffects model showed that the prevalence of HAls was higher $(P=0.04)$ in patients who smoked than those who did not smoke (OR: $1.40,95 \% \mathrm{Cl}: 1.02-1.93)$. The heterogeneity did not exist among the studies $\left(P=0.59,1^{2}=0 \%\right)$.

Underlying disease: 5 studies $(17,19-22)$ reported the underlying disease of 322 with and 1,657 patients without HAls. The random-effects model showed that the prevalence of HAls was significantly higher $(P=0.0005)$ in patients with underlying disease than those without underlying disease (OR: $2.66,95 \% \mathrm{Cl}$ :

1.53-4.62). There was a high heterogeneity among the studies $\left.\hat{\tau}^{2}=0.33(P<0.01), I^{2}=87 \%\right)$.

Use of antibiotics: 10 studies (13-22) reported the use of antibiotics of 561 with and 4,306 patients without HAls. Fixed-effects model showed that the prevalence of HAls was significantly higher $(P<0.01)$ in patients who used antibiotics than those who did not use antibiotics (OR: 2.77, 95\% Cl: 2.35-3.27). The heterogeneity did not exist among the studies $\left(P=0.06, \mathrm{I}^{2}=45 \%\right)$.

\section{Discussion}

Our systematic review and meta-analysis first provided a comprehensive analysis of risk factors on HAls among TB hospitalized patients in Chinese general hospitals. Our review found that older than 65 years, presence of complication, presence of diabetes mellitus, invasive procedure, longer than 15 days of hospitalization stay, secondary tuberculosis, smoking, presence of underlying disease, and use of antibiotics were the main risk factors which had a negative impact on HAls among TB hospitalized patients in Chinese general hospitals. These findings provided evidence for the policy makers and hospital managers to make effective infection prevention and control measures to constrain the rising of HAls.

Our systematic review found that TB hospitalized patients older than 65 years were more susceptible to HAls than those younger than 65 years (OR: 2.89[2.01-4.15]). The number of aged population is rapidly rising in the globe. 1 in 6 people beyond the age of 65 years has been estimated in the world in 2050, which is much higher than 1 in 11 in 2019 (23). Elderly TB patients are recognized as the immunecompromised patients, who are at high risk of acquiring HAls (24). This suggests that the elderly TB patients should be set as the priority and the surveillance of the elderly TB patients should be strengthened. Thus, it can result in decreasing the risk of getting HAls among aged TB patients. 
Presence of complication, diabetes mellitus, underlying disease, and secondary tuberculosis were found the main factors associated with high prevalence of healthcare-associated TB in our review. All of them mainly deteriorated the TB patients' immune systems. Consequently, TB patients were more susceptible to HAls compared with those without above conditions. One study has confirmed that it was 2.5 times more likely to develop TB among patients with diabetes mellitus in developed countries (25). It was also found that diabetes mellitus was highly associated with multi-drug resistant TB (MDR-TB) in Asia (OR: $1.40[1.01-1.95])$ in a systematic review and meta-analysis $(26,27)$. Presence of complication, diabetes mellitus, underlying disease, and secondary tuberculosis definitely affect the healthcare-associated TB patients' safety and prognosis, and put a challenge to the worldwide health system infection control strategy and clinical management, which further alert the global health development without any control measure.

The hazard of acquiring HAls among TB hospitalized patients who had invasive procedure was higher than those without invasive procedure (3.80 [2.25-6.42]) in our review. Invasive procedure was actually not frequently reported that had a negative impact on healthcare-associated TB in existing research. However, invasive procedure, such as indwelling invasive device and surgery, indeed make the TB hospitalized patients predisposed to HAls. A single-centre point-prevalence survey in an American hospital showed that $96.8 \%$ of hospitalized adult patients had at least one indwelling device (28). It indicated that invasive procedure was still widely adopted as a treatment among hospitalized patients, which put the patients into high exposure to HAls.

Our review also found that smoking increased the risk of obtaining HAls among TB hospitalized patients (OR: 1.40 [1.02-1.93]). Smoking, as a risk behaviour, can compromise the successful TB treatment due to poor adherence to the treatment among TB patients (29). Additionally, the majority of TB hospitalized patients belong to pulmonary TB. This suggests that pulmonary TB hospitalized patients are more likely to acquire healthcare-associated pneumonia. Therefore, TB patients who smoke, especially male patients, need to experience aspiration of sputum, fibrotic bronchoscope, and trachea cannula and so on due to the rising respiratory secretions in lung, thereby increasing the likelihood of HAls. Personal intervention should be made for TB patients who smoke to stop the risky behaviour. Hence, the treatment of TB could be not more sophisticated and decrease the risk of getting HAls.

TB hospitalized patients who stayed in hospital longer than 15 days were found to be more likely to obtain HAls compared with those who had less than 15 days of hospitalization (OR: 2.09[1.64-2.64]) in our review. Prolonged hospitalization stay extends the exposure to HAls among TB hospitalized patients, which is confirmed in some studies $(30,31)$. TB hospitalized patients who stay longer in hospital are more likely to have underlying disease or complications or invasive procedure and so on $(32,33)$. As previously mentioned, they promote the probability of the exposure to HAls for TB hospitalized patients. It is necessary for the hospitals to shorten the hospitalization stay for the TB patients in order to lower the risk of HAls exposure. 
TB hospitalized patients were more risky to get HAls if they used antibiotics during the treatment compared with their counterparts (OR: 2.77[2.35-3.27]). This finding is consistent with current studies (34). Use of anti-tuberculosis drug is the main way to treat TB for a long period (21). During the treatment, it is common to use antibiotics for TB patients concurrently. As a consequence, an increasing number of TB patients have been infected with multi-drug resistance. Goedele et al. also mentioned that successful TB treatment is compromised by drug resistance because of irrational use of antibiotics to treat TB (29). This indicates that prudent and high-quality antibiotics prescription and rational use of antibiotics are essential to constrain the overuse of antibiotics, thereby reduction in the occurrence of healthcareassociated TB. Moreover, antimicrobial stewardship program has been widely recommended as one way to achieve the rational use of antibiotics, including making straightforward and strict rational use of antibiotics guidelines and regulations, improving the clinical doctors' antibiotics prescription behaviour, and increasing the awareness of antimicrobial resistance among the public $(35,36)$.

The key to preventing the healthcare-associated TB after clearly investigating the risk factors associated with high occurrence of healthcare-associated TB is to implement effective infection prevention and control measures. Current literature has suggested that the exposure and transmission of healthcareassociated TB can be reduced with the implementation of infection prevention and control guidelines, which can increase the identification and isolation of the potential healthcare-associated TB patients (37). The United States, $\mathrm{WHO}$, and other institutions have recommended effective infection prevention and control measures to decrease the occurrence of healthcare-associated TB, particularly a hierarchy of effective infection control measures, including administrative controls, environmental controls, and personal respiratory protection (38). Specially, the administrative controls are considered as the first and most important component to decrease the exposure to healthcare-associated TB. It is also required that more cost-effective infection prevention and control measures should be widely applied in routinely medical treatment and clinical management to healthcare-associated TB. Hence, the exposure and transmission of the healthcare-associated TB can be reduced and prevented.

Our systematic review and meta-analysis also has some limitations. First, the included studies were mostly published in Chinese journals since they were conducted in Chinese general hospitals. It encourages the researchers to publish their findings about risk factors for healthcare-associated TB in English journals to share the advanced knowledge. Second, we found the included studies were all conducted in a single hospital. It is required that multi-centre studies could be undertaken in future research to strengthen the current evidence base.

\section{Conclusions}

Older than 65 years, presence of complication, presence of diabetes mellitus, invasive procedure, longer than 15 days of hospitalization stay, secondary tuberculosis, smoking, presence of underlying disease, and use of antibiotics were the main risk factors which had a negative impact on HAls among TB hospitalized patients in Chinese hospitals. These findings provided evidence for the policy makers and hospital managers to make effective infection prevention and control measures to constrain the rising of 
HAls.. It is also required that more cost-effective infection prevention and control measures should be widely applied in routinely medical treatment and clinical management to healthcare-associated TB. Hence, the exposure and transmission of the healthcare-associated TB can be reduced and prevented.

\section{Declarations}

\section{Ethics approval and consent to participate}

It is not applicable.

\section{Consent for publication}

It is not applicable.

\section{Availability of data and materials}

The datasets and materials analysed during the current study are available from the corresponding author on reasonable request.

\section{Author contributions}

The systematic review and meta-analysis was conducted under the charge of H.L. X.L. and N.R. searched the databases to find the relevant articles and assessed the quality of the included studies. X.L. undertaken the statistical analysis. X.L. and N.R. drafted and revised the manuscript. M.Z. adjusted the tables and figures. H.L. and Z.F. reviewed the manuscript, provided the feedbacks and did the proofreading.

\section{Funding}

Our study was funded by Seed project grant of Wuhan University Office of International Affairs.

\section{Competing interests}

The author(s) declared no potential conflicts of interest with respect to the research, authorship, and/or publication of this article.

\section{Acknowledgements}

We appreciated it that all the authors on the list made their own contribution to this manuscript.

\section{References}

1. World Health Organization. Global Health Estimates: Life expectancy and leading causes of death and disability 2020 [cited 2021 June 10]. Available from:

https://www.who.int/data/gho/data/themes/mortality-and-global-health-estimates. 
2. World Health Organization. Global Tuberculosis Report 20202020 [cited 2021 June, 10]. Available from: https://apps.who.int/iris/bitstream/handle/10665/336069/9789240013131-eng.pdf.

3. Xie ZY, Huang GF, Gao H, Chi YQ, Wang YX, Pang Y, et al. Nosocomial Infection Surveillance in a Tuberculosis Specialized Hospital in China. Biomedical Environmental Sciences. 2017;30(9):691-4.

4. Liu X, Cui D, Li H, Wang Q, Mao Z, Fang L, et al. Direct medical burden of antimicrobial-resistant healthcare-associated infections: empirical evidence from China. Journal of Hospital Infection. 2020;105(2):295-305.

5. World Health Organization. Report on the Burden of Endemic Health Care-Associated Infection Worldwide: A systematic review of the literature 2011 [cited 2021 June 10]. Available from: http://apps.who.int/iris/bitstream/handle/10665/80135/9789241501507_eng.pdf?sequence=1.

6. World Health Organization. Patient Safety 2019 [cited 2021 June 10]. Available from: https://www.who.int/news-room/fact-sheets/detail/patient-safety.

7. Wang J, Liu F, Tartari E, Huang J, Harbarth S, Pittet D, et al. The Prevalence of Healthcare-Associated Infections in Mainland China: A Systematic Review and Meta-analysis. Infection control and hospital epidemiology. 2018;39(6):701-9.

8. Yin Y, Zhao C, Li H, Jin L, Wang Q, Wang R, et al. Clinical and microbiological characteristics of adults with hospital-acquired pneumonia: a 10-year prospective observational study in China. European Journal of Clinical Microbiology \& Infectious Diseases. 2021;40(4):683-90.

9. Sevin T, Daniau C, Alfandari S, Piednoir E, Dumartin C, Blanchard H, et al. Patterns of antibiotic use in hospital-acquired infections. Journal of Hospital Infection. 2021;114:104-10.

10. Adam N, Pallikadavath S, Cerasuolo M, Amos M. Investigating the risk factors for contraction and diagnosis of human tuberculosis in Indonesia using data from the fifth wave of RAND's Indonesian Family Life Survey (IFLS-5). Journal of Biosocial Science. 2021;53(4):577-89.

11. Minstry of Health. Diagnostic criteria of nosocomial infection (in Chinese) 2001 [cited 2021 June 10]. Available from:

http://www.nhfpc.gov.cn/yzygj/s3593/200804/e19e4448378643a09913ccf2a055c79d.shtml.

12. Critical Apprasial Skills Programme (CASP). CASP Checklist 2018 [cited 2021 July 21]. Available from: https://casp-uk.net/casp-tools-checklists/.

13. Chen L, Li H, Chen J. Influencing factors and preventive measures for nosocomial infections in patients with pulmonary tuberculosis (in Chinese). Journal of Traditional Chinese Medicine Management. 2018;26(4):95-7.

14. Dai J, Su F, Huang M, Yang S, Deng F. Risk factors for nosocomial infections in patients with pulmonary tuberculosis (in Chinese). Chinese Journal of Nosocomiology. 2014;24(21):5350-4.

15. Liu X, Ding L, Chen H, Xia J. Investigation and analysis of nosocomial infection in pulmonary tuberculosis (in Chinese). Journal of Tropical Medicine. 2015;15(2):221-3.

16. Zeng Q. Analysis of related factors and nursing strategy of nosocomial infection in patients with pulmonary tuberculosis (in Chinese). Jinlin Medical Journal. 2015;36(8):1641-2. 
17. Zhang H, Zhang C, Wen Z. Analysis of the related factors for TB hospitalized patients with nosocomial infection (in Chinese). Modern Preventive Medicine. 2012;39(24):6417-9.

18. Zhong $K$, Zhong M, Zeng Q. Investigation and strategies on influencing factors for nosocomial infections in patients with pulmonary tuberculosis (in Chinese). Modern Clinical Nursing. 2010;9(3):3-5.

19. Zhou X, Yuan W, Han Y, Zhang J, Zhang X, Wang Y. Clinical characteristics and preventive measures of nosomial infections in patients with open tuberculosis during hospitalisation (in Chinese). Chinese Journal of Nosocomiology. 2018;28(19):2932-5.

20. Huang W, Wang $H$, Yang W, Chen Z. Pathogens and imaging features of nosocomial infection in patients with pulmonary tuberculosis (in Chinese). Chinese Journal of Nosocomiology. 2019;29(3):351-4.

21. Jiang H, Shi S, Han X, Bao C, Li G. Etiological characteristics and risk factors of nosocomial infection in elderly patients with pulmonary tuberculosis (in Chinese). Chinese Journal of the Frontiers of Medical Science. 2019;11(10):149-52.

22. Xiang $C$, Tang $H$, Yang $X$, Jiang Q, Ma Q. Influencing factors and etiological characteristics of nosocomial infection in tuberculosis patients (in Chinese). Chinese Journal of Nosocomiology. 2019;29(17):2639-42.

23. Sharma M, Onozaki I, Nunn P. TB in older people in Asia: why it is important. The International Journal of Tuberculosis and Lung Disease. 2021;25(7):521-4.

24. Suzuki T, Kato T, Ohnishi R, Yasuda S, Sano K, Shirakami Y, et al. Clinical Characteristics of Nursingand Healthcare-Associated Tuberculosis. Diseases. 2018;6(4):101.

25. Khalil NH, Ramadan RA. Study of risk factors for pulmonary tuberculosis among diabetes mellitus patients. Egyptian Journal of Chest Diseases and Tuberculosis. 2016;65(4):817-23.

26. Liu Q, Li W, Xue M, Chen Y, Du X, Wang C, et al. Diabetes mellitus and the risk of multidrug resistant tuberculosis: a meta-analysis. Scientific Reports. 2017;7(1):1090.

27. Huang $D$, Wang $Y$, Wang Y, Liang ZJAoPM. The impact of diabetes mellitus on drug resistance in patients with newly diagnosed tuberculosis: a systematic review and meta-analysis. 2020. 2020;9(2):152-62.

28. Chen S, O'Malley M, Chopra V. How common are indwelling devices in hospitalized adults? A contemporary point prevalence study in a tertiary care hospital. American Journal of Infection Control. 2021;49(2):194-7.

29. Louwagie GM, Morojele N, Siddiqi K, Mdege ND, Tumbo J, Omole O, et al. Addressing tobacco smoking and drinking to improve TB treatment outcomes, in South Africa: a feasibility study of the ProLife program. Translational Behavioral Medicine. 2019;10(6):1491-503.

30. Robertson C, Pan J, Kavanagh K, Ford I, McCowan C, Bennie M, et al. Cost burden of Clostridioides difficile infection to the health service: A retrospective cohort study in Scotland. Journal of Hospital Infection. 2020;106(3):554-61. 
31. Bastiaens GJH, Baarslag T, Pelgrum C, Mascini EM. Active surveillance for highly resistant microorganisms in patients with prolonged hospitalization. Antimicrobial Resistance \& Infection Control. 2020;9(1):8.

32. Patty CM, Sandidge-Renteria A, Orique S, Dixon C, Camarena E, Newsom R, et al. Incidence and Predictors of Nonventilator Hospital-Acquired Pneumonia in a Community Hospital. Journal of Nursing Care Quality. 2021;36(1).

33. Palacios-Baena ZR, Giannella M, Manissero D, Rodríguez-Baño J, Viale P, Lopes S, et al. Risk factors for carbapenem-resistant Gram-negative bacterial infections: a systematic review. Clinical Microbiology and Infection. 2021;27(2):228-35.

34. Magill SS, O'Leary E, Ray SM, Kainer MA, Evans C, Bamberg WM, et al. Antimicrobial Use in US Hospitals: Comparison of Results From Emerging Infections Program Prevalence Surveys, 2015 and 2011. Clinical Infectious Diseases. 2020;72(10):1784-92.

35. Bolla C, Di Pietrantonj C, Ferrando E, Pernecco A, Salerno A, D'Orsi M, et al. Example of antimicrobial stewardship program in a community hospital in Italy. Médecine et Maladies Infectieuses. 2020;50(4):342-5.

36. Perron J, Baldolli A, Isnard C, de La Blanchardière A, Saint-Lorant G. Assessing the relevance of carbapenem prescriptions by an antibiotic stewardship team. Médecine et Maladies Infectieuses. 2020;50(4):346-51.

37. Chen B, Liu M, Gu H, Wang X, Qiu W, Shen J, et al. Implementation of tuberculosis infection control measures in designated hospitals in Zhejiang Province, China: are we doing enough to prevent nosocomial tuberculosis infections? BMJ open. 2016;6(3):e010242.

38. Collins JM, Blumberg HM. The blueprint for prevention of nosocomial tuberculosis transmission is clear, but why don't we have the will to follow it? Clinical Microbiology and Infection. 2020;26(8):970-2.

39. Gong L, Wang Y. Survey on control of nosocomial infections in TB specialist hospital (in Chinese). Chinese Journal of Nosocomiology. 2013;23(15):3697-9.

\section{Figures}




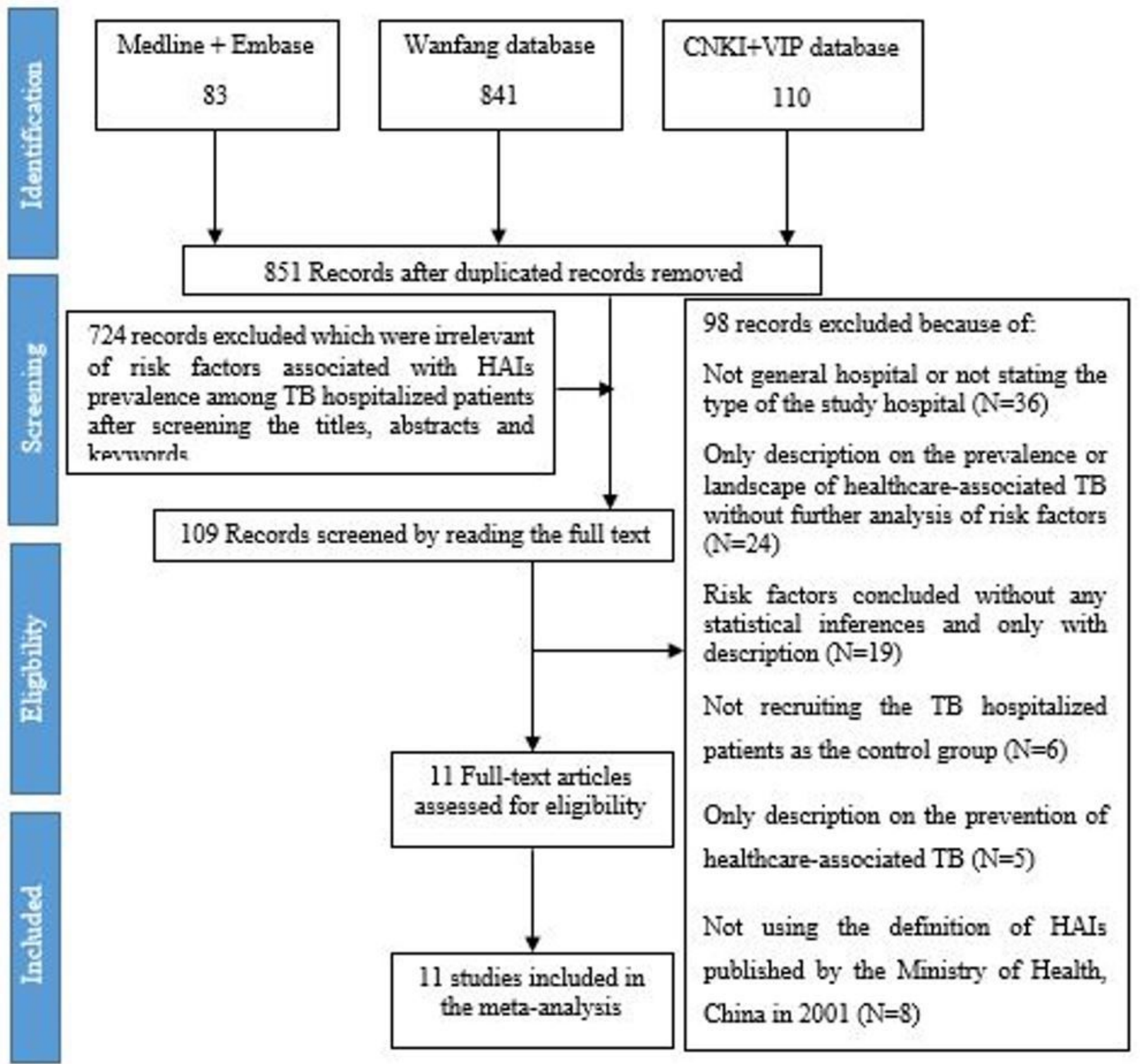

Figure 1

Flow chart of the searching relevant of published articles from the included databases Note:

Abbreviations: CNKI: China National Knowledge Infrastructure; Wangfang database: Chinese Wan Fang digital database; VIP: Chinese Science and Technique Journals Database; HAls: Healthcare-associated infections; TB: Tuberculosis

\section{Supplementary Files}

This is a list of supplementary files associated with this preprint. Click to download. 
- Supplementarylnfo.docx

Page 19/19 